\title{
ОСОБЛИВОСТІ ЦИВІЛЬНОГО ЗАХИСТУ ІНФОРМАЦІЙНОГО ПРИВАТНОГО ПРАВА ОСОБИ
}

Гуйван П. Д.

Наукова стаття присвячена дослідженню актуального питання правової охорони приватності людини. У роботі розглянуто проблеми захисту інформачійних прав людини. Встановлено, що право індивіда на інформацію слід розділити на недоторканність його персональних даних та можливість публічного доступу до окремих даних про особу, які мають значний суспільний інтерес. Якщо ідеться про персональні дані, то застосовується цивільно-правовий метод захисту права, якщо ж ідеться про поширення суспільно важливих відомостей про суб'єкта, то спосіб захисту має бути публічним (адміністративна юрисдикція).

Ключові слова: право на приватність, публічно-правовий захист, персональні дані.

Научная статья посвящена исследованию актуального вопроса правовой охраны приватности человека. Установлено, что право индивида на информацию следует разделить на неприкосновенность его персональных данных и возможность публичного доступа к отдельным данным о личности, имеющим значительный общественный интерес. Если речь идет о персональных данных, то применяется гражданско-правовой метод защиты права, если речь идет о распространении общественно важных сведений о субъекте, то способ защиты должен быть публичным (административная юрисдикция).

Ключевые слова: право на приватность, публично-правовая защита, персональные данные.

The scientific article is devoted to the research of the actual issue of legal protection of human privacy. It is noted that this aspect of being an individual is quite diverse and covers $a$ wide range of relationships: the privacy of the individual's housing rights, his correspondence, the right to a safe environment, etc. The doctrinal definition of the concept of "private life" is analyzed and its relation with practical enforcement approaches in the commented sphere is established. Particular attention is paid to the case law of the European Court of Human Rights, which interprets a person's right to privacy as a set of powers regarding the privacy of a person in the personal sphere, relating to the ability to define his or her life and order of acquaintance with others, the person's right to a safe environment, access to information, related to the person and determining his legal status, etc.

Special attention is paid to the protection of information rights in the article. It has been established that the right of an individual to information should be divided into the integrity of his or her personal data (in the broad sense, this includes any confidential information, that is, the range of protected objects is wider than the classic "personal data") and the possibility of public access to certain personal data of significant public interest. Therefore, as a consequence, often the personal informational interest of the person overlaps with his public aspirations. Therefore, personal phenomena can relate to events, phenomena and circumstances of the social level, and thus to acquire a legal significance of a public factor. Therefore, when

Гуйван П. Д., 2019 carrying out protective enforcement actions, it is important to determine what nature, which particular relations with access to information are directed, whether private or public, and, accordingly, apply the appropriate safeguard mechanism. A specific example of a court case shows that in case of interference by other persons in the subjective law, including information content, there is an urgent problem in determining the public or private legal protection. When it comes to a person's personal data and other sensitive information about him, the civil law method applies, but when it comes to the dissemination of socially important information about a subject, the method of protection should be public (administrative jurisdiction).

Key words: right to privacy, public-legal protection, personal data.

Постановка проблеми та їі актуальність. Прикладом значного поступу у сфері комунікації у сучасному суспільстві $\epsilon$ стрімкий розвиток інформаційних відносин. Наразі вони активно вдосконалюються у напрямі гарантування основоположних принципів, що забезпечують реалізацію прав учасників обміну інформацією, інформаційними продуктами та послугами. При цьому захист прав людини в галузі інформації та комунікації $\epsilon$ основною засадою функціонування демократичної держави. Закони про головні інформаційні права мають бути спрямовані на забезпечення збалансованості і рівності усіх суб'єктів правовідносин у сфері свободи слова та обміну інформацією, але вони також гарантують обмеження інформації, забороненої законом та правилами моралі. У нинішніх динамічних умовах розвитку громадянського суспільства діяння держави як гаранта соціального прогресу та основних прав людини мають спрямовуватися на встановлення чіткого та зрозумілого механізму інформаційного обігу, який мусить регулювати порядок доступу, поводження та встановлювати регламенти збору, обробки, зберігання, поширення чи передачі інформації, яка захищається державою (державна таємниця, конфіденційна інформація, персональні дані, авторські права чи інтелектуальна власність), а також регламентувати роботи з інформаційними ресурсами, що містять таку інформацію [1].

Згідно з приписом ст. 271 ЦК України зміст особистого немайнового права становить можливість фізичної особи вільно, на власний розсуд визначати свою поведінку у сфері свого приватного життя. Одним з основоположних прав кожної людини $\epsilon$ право отримувати, збирати, поширювати та використовувати інформацію. Як бачимо, інфосфера буття окремого індивідуума $\epsilon$ досить масштабною і різноманітною. Кожна із зазначених вище правомочностей має свої особливості регулювання, які встановлюються залежно від умов їхньої реалізації та спрямованості на задоволення потреб людини у використанні такого блага. Скажімо, пошук інформації як процес визначається у теорії шля- 
хом вчинення дій із звернення особи до певного органу, установи чи іншого суб'єкта за отриманням необхідної інформації. Одержанням особистих чи публічних відомостей вважається перехід до такого запитувача у володіння та утримання необхідних йому даних від персони, яка володіє ними, на законних підставах.

Суб'єктивне нематеріальне право фізичної особи на інформацію (ст. 302 цК України) $є$ невід'ємним елементом і важливою складовою частиною такого поняття, як «особисте життя». Як же з точки зору правової науки визначається подібне явище? У доктрині існує значне розмаїття поглядів на сутність особистого життя, більшість $з$ яких $\epsilon$ спробами визначення соціологічного аспекту цього поняття. При цьому науковці переважно розглядають його як синонім терміна «приватне». Це підтверджується філологічним аналізом слів «приватний» $\mathrm{i}$ «особистий», кожне з яких виражає ту сферу відносин, яка безпосередньо стосується якої-небудь особи, пов'язана з нею; виражає особливості, нахили тощо якої-небудь особи; характеризує належність певних якостей конкретному суб'єкту [2, с. 153]. Однак з методологічної точки зору слід погодитися з науковцями, котрі вважають, що поняття приватного життя $\epsilon$ ширшим за змістом та таким, що виходить за рамки суто особистих, сімейних відносин [3, с. 105]. Подібний підхід в оцінках коментованого явища притаманний і європейським правовим інституціям. Так, Європейський суд з прав людини, застосовуючи на практиці ст. 8 Конвенції про захист прав людини і основоположних свобод, тлумачить право особи на приватність як комплекс повноважень щодо недоторканності особи в особистісній сфері, які стосуються можливості визначати своє життя і порядок ознайомлення з ним інших осіб, права особи на безпечне довкілля, на доступ до інформації, пов'язаної з особою та визначенням іiі правового статусу.

При цьому кожна особистість самостійно визначає зміст та обсяг свого приватного буття і можливість ознайомлення з ним інших осіб. Фізична особа має право на збереження у таємниці обставин своєї особистої сфери. Вони можуть бути розголошені лише за умови, що містять ознаки правопорушення, якщо це підтверджено рішенням суду, а також за згодою особи. Складовою частиною приватного життя особи $є$ їі інформаційна приватність. Право на інформаційну приватність включає в себе право на самостійне визначення режиму доступу до відомостей персонального характеру (у т. ч. їхє втаємничення), право на ознайомлення з даними про себе в органах публічної влади та внесення змін до відповідних баз даних тощо [4, с. 2].

Але, як відомо, суб'єктивне право набуває дієвості лише тоді, коли існує ефективний юридичний механізм його захисту. Забезпечити ефективність правового механізму охорони приватності особи можна лише тоді, коли межі особистого життя будуть визначені більш чітко та однозначно. Наприклад, в окремих відносинах, що складаються у соціумі, грань між суспільно корисним і приватним практично стирається, адже елемент публічності може проявлятися у, здавалося б, виключно особистісних взаєминах і інтересах особи. Хоча дана ознака в діяннях конкретного індивіда може не усвідомлюватися ним самим, а його поведінка оцінюватиметься лише як прояв особистого життя, вона може все ж певним чином стосуватися подій, явищ та обставин суспіль- ного рівня, набуваючи юридичного значення публічного чинника. 3 правової точки зору у разі втручання інших осіб у суб'єктивне право, зокрема інформаційного змісту, з'являється актуальна проблема визначення публічно-правового чи приватноправового способу застосування відповідного охоронного інструментарію.

Аналіз останніх досліджень і публікацій. Недопущення свавільного втручання у право особи на вільний інформаційний обіг як складову частину приватного життя $€$ однією з головних засад організації громадянського суспільства. Отже, дана сфера характеризується посиленням уваги сучасної правової науки в галузі особистих інтересів людини, особливо з урахуванням наявності зазначеного публічного елементу. У літературі вказані питання висвітлені у працях таких дослідників, як М.І. Хавронюк, В.М. Тертишник, С.Є. Горбатюк, В.В. Коваль, Ю.І. Римаренко, О.І. Яременко, В.С. Сивухін, П.П. Андрушко, О.В. Нестеренко, І.В. Арістов, О.М. Готін. У роботах даних вчених проаналізований широкий спектр відносин щодо здійснення та захисту права на доступ до персональної та публічної інформації. Однак маємо зазначити, що в науковій літературі не проводилося детального вивчення сутнісних відмінностей організації практичної діяльності із особистою інформацією про людину (персональними даними) та відомостями, що становлять загальний суспільний інтерес. Оскільки національний правозахисний механізм стосується правил охорони доступу до публічних відомостей (Закон України «Про доступ до публічної інформації), мають бути детально вивчені міжнародні напрацювання у даній сфері з метою їхньої імплементації у національну правову систему. Це і становить головну мету даної праці.

Виклад основного матеріалу. У цивілістиці наголошується на неприпустимості необґрунтованого втручання у сферу особистого життя людини. Даний основоположний принцип означає вимогу забезпечення свободи особистості, яку інколи іменують суверенітетом особистості, вкладаючи у це поняття можливість індивіда визначати тип і характер поведінки, своє місце в суспільстві, в системі цивільних правовідносин тощо за власним розсудом [5, с. 9]. Європейський суд з прав людини неодноразово підкреслював, що будь-які особи, особливо держава, мусять ретельно та уважно ставитися до інформації про особу, не допускаючи порушень права на приватність, передбаченого Конвенцією. 3 огляду на це як зберігання державними органами інформації про особисте життя людини, так i iï використання $є$ втручанням у право на повагу до особистого життя, гарантованого пунктом 1 статті 8 Конвенції [6, п. 46]. Подібне втручання може бути визнане належним лише за наявності сукупності об'єктивних чинників, таких як передбаченість його законом, легітимна мета та прийнятність втручання у демократичному суспільстві. Оскільки призначенням Конвенції визнається необхідність захищати реальні права людини, а не ілюзорні, то справедливий баланс між різними інтересами, що розглядаються, може бути порушений не тільки тоді, коли відсутні положення для захисту гарантованих прав, а й коли їх не дотримуються належним чином [7, п. 56, 61].

Під дію 8 статті Конвенції підпадають житлові спори, екологічні (справи щодо забруднення довкілля), забезпечення належного медичного чи побутового обслуго- 
вування тощо, а також спори про порушення особистих інформаційних прав. Окрему категорію їх становлять ті, що пов'язані із правопорушеннями у площині збору, обробки, поширення даних про особу, які мають конфіденційний характер. Для українського суспільства найбільш характерними порушеннями у цій сфері $\epsilon$ неправомірне та не узгоджене 3 суб'єктом поширення відомостей про нього, які мають персональний характер. Найбільше поширюються такі протиправні вчинки у сфері трудових відносин та медичного обслуговування населення. При цьому, на жаль, причини нехтування особистими немайновими правами людини зазвичай криються у банальній неграмотності працівників, які за фаховим призначенням мусять працювати з персональними даними особи.

Так, в одній із судових справ, що розглядалася з даного приводу, відповідач - клінічна лікарня - обґрунтовував свої дії щодо надання третій особі - роботодавцеві - доступу до конфіденційної особистої інформації фізичної особи положеннями Закону України «Про доступ до публічної інформації» [8]. Однак даний Закон не може застосовуватися до регулювання приватних відносин стосовно розповсюдження особистої інформації та персональних даних людини. Твердження відповідача, що інформація, яку він надав третій особі, $\epsilon$ публічною, слід кваліфікувати як серйозну помилку. У правилі п. 1.1 Постанови пленуму Вищого адміністративного суду України № 10 від 29 вересня 2016 року «Про практику застосування адміністративними судами законодавства про доступ до публічної інформації» вказується, що відповідно до ст. 13 Закону «Про доступ до публічної інформації» публічною інформацією $є$ відображена або задокументована будь-якими засобами та на будь-яких носіях уся інформація, що перебуває у володінні суб'єктів владних повноважень, тобто органів державної влади, інших державних органів, органів місцевого самоврядування, органів влади Автономної Республіки Крим, інших суб'єктів, що здійснюють владні й управлінські функції відповідно до законодавства, рішення яких $\epsilon$ обов'язковими для виконання. Збір, обробка та поширення публічної інформації здійснюється розпорядниками публічної інформації. Розпорядниками інформації для цілей цього Закону визнаються зазначені суб'єкти владних повноважень. Оскільки дана інформація має публічний характер, то відносини, що випливають із факту іï надання чи в зв'язку з правопорушеннями даного закону, підлягають регулюванню адміністративними судами України, а цивільне процесуальне законодавство в цій сфері не застосовується. Однак лікувальні заклади не $\epsilon$ суб'єктами владних повноважень, що здійснюють владні й управлінські функції відповідно до законодавства, рішення яких $є$ обов'язковими для виконання. Отже, інформація, яка перебуває у їхньому розпорядженні, стосовно обсягу, характеру, призначення та ефективності таких послуг ніяк не може мати публічного характеру. Крім того, в певному обсязі, вказаному у законодавстві, інформація, що обробляється медичними закладами України, віднесена до конфіденційної інформації та персональних даних, обіг яких можливий виключно за згодою носія.

Згідно з українським законодавством не вся інформація про особу належить до ії персональних даних. Головним чинником, який відрізняє персональні дані від іншої інформації про особу, є можливість ідентифікувати суб'єкта. Так, у ст. 11 Закону України «Про інформацію» міститься таке визначення: «Інформація про фізичну особу (персональні дані) - відомості чи сукупність відомостей про фізичну особу, яка ідентифікована або може бути конкретно ідентифікована <...>». Аналогічне визначення персональних даних закріплене у статті 1 Закону «Про захист персональних даних»: «Персональні дані - відомості чи сукупність відомостей про фізичну особу, яка ідентифікована або може бути конкретно ідентифікована». Отже, якщо певна інформація дає змогу володільцю виділити із групи людей конкретну особу, то іï можна вважати персональними даними, тому дані, які не $\epsilon$ персональними даними, за певних обставин (коли вони дають змогу ідентифікувати особу) ними стають.

Також важливим у коментованому сенсі $\epsilon$ віднесення тієї чи іншої інформації до конфіденційної. Відповідно до Закону «Про доступ до публічної інформації» конфіденційною $є$ інформація, доступ до якої обмежено фізичною або юридичною особою, крім суб'єктів владних повноважень, та яка може поширюватися у визначеному ними порядку, за їхнім бажанням і відповідно до передбачених ними умов. Схоже визначення нам дає Закон «Про інформацію» у статті 21: «Конфіденційною $є$ інформація про фізичну особу, а також інформація, доступ до якої обмежено фізичною або юридичною особою, крім суб'єктів владних повноважень. Конфіденційна інформація може поширюватися за бажанням (згодою) відповідної особи й у визначеному нею порядку та відповідно до передбачених нею умов, а також в інших випадках, визначених законом». У низці випадків особливо чутлива для людини інформація визнається конфіденційною за прямою вказівкою закону. Наприклад, Закон «Про інформацію» вказує, що до конфіденційної інформації про фізичну особу належать, зокрема, дані про їі національність, освіту, сімейний стан, релігійні переконання, стан здоров'я, а також адресу, дату і місце народження.

У своєму рішенні Конституційний Суд України дав роз'яснення поняття «конфіденційна інформація» у справі за конституційним поданням Жашківської районної ради Черкаської області щодо офіційного тлумачення положень частин першої, другої статті 32, частин другої, третьої статті 34 Конституції України (справа № 2-рп-2012 від 20 січня 2012 року). Даючи офіційне тлумачення частин першої, другої статті $32 \mathrm{Koн}-$ ституції України, КСУ зазначив: «Інформація про особисте та сімейне життя особи (персональні дані про неї) - це будь-які відомості чи сукупність відомостей про фізичну особу, яка ідентифікована або може бути конкретно ідентифікована (національність, освіта, сімейний стан, релігійні переконання, стан здоров'я, матеріальний стан, адреса, дата і місце народження, місце проживання та перебування тощо, дані про особисті майнові та немайнові відносини цієї особи з іншими особами, зокрема членами сім'ї, а також відомості про події та явища, що відбувалися або відбуваються у побутовому, інтимному, товариському, професійному, діловому та інших сферах життя особи, за винятком даних стосовно виконання повноважень особою, яка займає посаду, пов'язану зі здійсненням функцій держави або органів місцевого самоврядування). Інформація про фізичну особу та членів іiї сім'ї $\epsilon$ конфіденційною 
і може бути поширена тільки за їх згодою, крім випадків, визначених законом, і лише в інтересах національної безпеки, економічного добробуту та прав людини».

Отже, орган конституційної юрисдикції вказав, що практично будь-яка інформація про особу, яка $\epsilon$ конфіденційною, може оброблятися (збиратися, використовуватися тощо) лише за згодою відповідного суб'єкта цих даних. Рішення Конституційного Суду України $\epsilon$ обов'язковими до виконання на території України (ст. 150 Конституції України). При цьому у рішенні КСУ не йдеться про те, що для кваліфікації інформації як конфіденційної має значення, у яких відносинах перебувають особа, що обробляє персональні дані у вигляді конфіденційної інформації, та суб'єкт таких відомостей - у адміністративних, господарських, цивільних чи трудових. У будь-якому разі важливо лише те, що відбувається обробка конфіденційної інформації про іншу особу, яка має здійснюватися виключно за згодою носія таких даних. Саме цей підхід відповідає сучасному розвитку європейського законодавства у сфері охорони особистих немайнових прав фізичної особи та нормам міжнародного права у цій галузі, зокрема й нормам Європейській Конвенції з прав людини.

Проте законодавством може бути заборонене віднесення певних персональних даних фізичної особи до конфіденційної інформації. Відкритою $\epsilon$, наприклад, така інформація: прізвища, імена, по батькові фізичних осіб, які отримали бюджетні кошти, одержали у володіння, користування чи розпорядження державне та/ або комунальне майно (частина п'ята статті 6 Закону «Про доступ до публічної інформації»); персональні дані, що стосуються здійснення особою, яка займає посаду, пов'язану з виконанням функцій держави або органів місцевого самоврядування, посадових або службових повноважень (частина друга статті 5 Закону «Про захист персональних даних»). Таким чином, персональні дані відходять на другий план, а не перший план виходить доступ до публічної інформації, коли ідеться про використання комунального або державного майна, про бюджетні кошти, декларації, а також про виконання службових обов'язків на державній службі.

Національне законодавство припускає, що певна інформація, що становить суспільний інтерес (суспільно необхідна інформація) (частина друга статті 13 Закону № 2939-VI), може перебувати у володінні державних та комунальних медичних установ. Вони можуть надавати публічну інформацію, пов'язану з виконанням їхніх суспільних обов'язків, в межах делегованих державою функцій щодо охорони здоров'я відповідно до закону (частина перша статті 13 Закону № 2939-VI). Це, зокрема, відомості, необхідні для урахування потреб населення у медичному обслуговуванні, щодо забезпечення належної якості такого обслуговування, своєчасності, доступності для громадян, ефективного використання матеріальних, трудових і фінансових ресурсів (частина третя статті 16 Основ законодавства України про охорону здоров'я). Скажімо, публічно доступною має бути інформація про обсяги надання медичних послуг, їхню якість, періоди роботи установи тощо.

Отже, потрібно враховувати, що державні та комунальні заклади охорони здоров'я $є$ суб'єктами господа- рювання, на яких поширюється вимога пункту 4 частини другої статті 13 Закону № 2939-VI щодо віднесення до публічної інформації відомостей про їхню діяльність, які становлять суспільний інтерес. Водночас розпорядники інформації, визначені частиною першою статті 13 цього Закону, які володіють конфіденційною інформацією, можуть поширювати іï лише за згодою осіб, які обмежили доступ до інформації, а за відсутності такої згоди лише в інтересах національної безпеки, економічного добробуту та прав людини (частина друга статті 7 Закону № 2939-VI). Ці положення узгоджуються 3 положеннями частини другої статті 32 Конституції України, відповідно до якої не допускається збирання, зберігання, використання та поширення конфіденційної інформації про особу без її згоди, крім випадків, визначених законом, і лише в інтересах національної безпеки, економічного добробуту та прав людини.

Повертаючись до вже згадуваної судової справи № 554/4546/19, можемо, звісно, зробити абстрактне припущення, що запитувач інформації - приватний роботодавець - та надавач іï - міська лікарня - настільки високо цінують персону конкретного працівника, що вважають відомості про стан здоров'я даної особи предметом величезного суспільного інтересу, а тому на дану персональну та конфіденційну інформацію мають поширюватися винятки, які дозволяють іiї надавати в публічному порядку. Але навіть у такому разі слід зазначити, що бажання запитувача та розпорядника інформації для надання їй публічного характеру замало. Згідно з приписом Закону розпорядник при визначенні того, $є$ чи немає обмежень в доступі, повинен застосовувати певну досить складну процедуру, так званий трискладовий тест - вимоги, передбачені частиною другою статті 6 Закону № 2939-VI, $з$ урахуванням особливостей відповідних положень [9]. Застосування цією процедури до особи, яка не $\epsilon$ публічною, практично не дає змоги кваліфікувати як публічно значущу конфіденційну інформацію про неї.

3 проведеного дослідження можемо зробити певні висновки. У роботі показано та проілюстровано на конкретному прикладі, що правове поняття «приватне життя» у практичному застосуванні не має однозначної визначеності. По-перше, воно охоплює широкий спектр питань індивідуального буття людини, серед яких можна виділити право на недоторканність житла, кореспонденції, на безпечне довкілля, інформаційні права особи. По-друге, правовий статус стосовно останніх повноважень, а саме права на інформацію, слід розділити на недоторканність персональних даних індивіда (у широкому сенсі це включає будь-які відомості, що мають конфіденційний характер, тобто коло об'єктів, що захищаються, ширше, ніж класичні персональні дані) та на можливість публічного доступу до окремих даних про особу, які мають значний суспільний інтерес. Отже, часто особистий інформаційний інтерес людини стикається з їі суспільними прагненнями, тому при здійсненні захисних правозастосовних дій важливо визначитися, який характер, яку спрямованість мають конкретні відносини з доступу до інформації (вони приватні чи публічні). 3 огляду на це необхідно застосовувати відповідний охоронно-правовий механізм. 


\section{Література}

1. Проєкт Концепції інформаційної безпеки України. URL: https: / /www.osce.org/uk/fom/175056?download=true.

2. Малеина М.Н. Личные неимущественные права граждан: понятие, осуществление, защита. Москва : M3 Пресс, 2001. 244 с.

3. Кулініч 0.0. Загальні положення про інформацію з обмеженим доступом в цивільному праві : монографія. Одеса : Видавництво «Букаєв Вадим Вікторович», 2008. 243 c.

4. Андрієвська 0.0. Охорона та захист прав на приватне життя особи. Часопис Академії адвокатури України. 2012. № 14 (1). С. 1-6.

5. Цивільне право : підручник : у 2-х ч. / О.А. Підопригора, Д.В. Боброва, А.С. Довгерт та ін. / за ред. О.В. Дзери. Київ : Вентурі, 1997. Ч. 1. 544 с.
6. Рішення ЄСПЛ від 4 травня 2000 року у справі «Ротару проти Румунії», заява № 28341/95, URL: http://search. ligazakon.ua/l_doc2.nsf/link1/SO2445.html.

7. Рішення ЄСПЛ від 16 листопада 2004 року, остаточне від 16 лютого 2005 року у справі «Морено Гомес проти Іспанії» (“Moreno Gomez v. Spain”), заява № 4143/02. URL: https://hudoc.echr.coe.int/eng\#\{"itemid":["001-67478"]\}.

8. Справа № 554/4546/19. Архів Октябрського районного суду м. Полтави за 2019 рік.

9. Гуйван П.Д. Обмеження допуску до публічної інформації: законодавство та реалії. Науковий вісник публічного та приватного права. 2019. № 3.

Гуйван П. Д., кандидат юридичних наук, заслужений юрист України, професор Полтавського інституту бізнесу 